\title{
Stratifikasi Masyarakat dalam Al-Quran
}

\author{
Muhamad Murtado \\ Jurusan Ilmu Hadis Fakultas Ushuluddin dan Adab Universitas Islam Negeri Sultan Maulana \\ Hasanuddin Banten \\ muhammadmurtado12@gmail.com
}

\begin{abstract}
KATA PENGANTAR
Puji dan syukur kita panjatkan atas kehadirat Allah SWT. Yang mana telah memberikan rahmat serta hidayah-nya kepada kita semua, sehingga saya mampu menyusun makalah yang berjudul Stratifikasi Masyarakat dalam Al-Qur'an. Shalawat dan salam semoga tercurah limpahkan kepada junjungan kita yakni nabi besar Muhammad SAW. Kepada keluarganya, sahabatnya, dan kita selaku umatnya. Penulis tentu menyadari bahwa makalah ini masih jauh dari kata sempurna dan masih banyak terdapat kesalahan serta kekurangan di dalamnya. Untuk itu, penulis mengharapkan kritik serta saran dari pembaca untuk makalah ini, supaya makalah ini nantinya dapat menjadi makalah yang lebih baik lagi. Kemudian apabila terdapat banyak kesalahan pada makalah ini penulis mohon maaf yang sebesar-besarnya. Demikian, semoga makalah ini dapat bermanfaat. Terima kasih.
\end{abstract}

Tangerang, 21 Februari 2019

Hormat Saya

DAFTAR ISI 


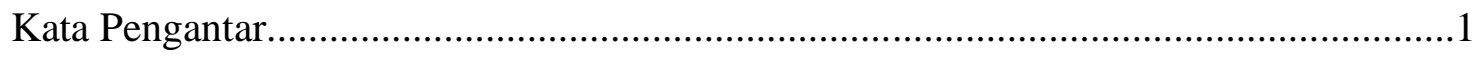

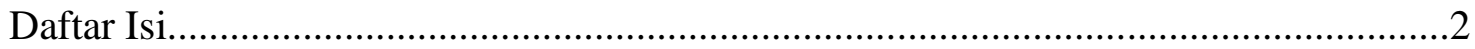

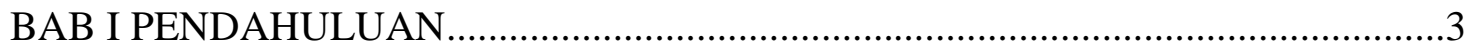

A. Latar Belakang.......................................................................................

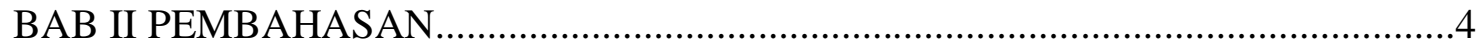

A. Stratifikasi Mayarakat Menurut Al-Qur'an....................................................4

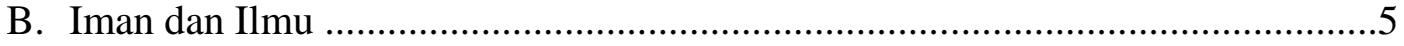

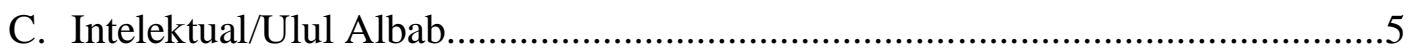

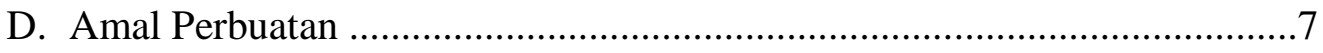

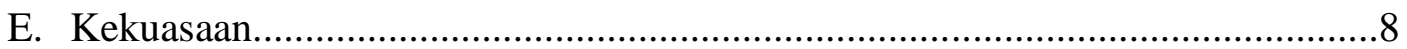

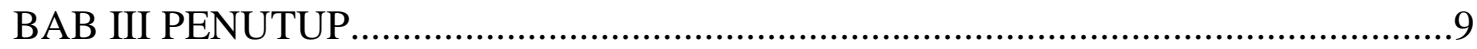

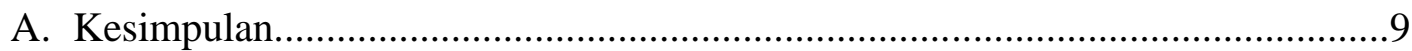

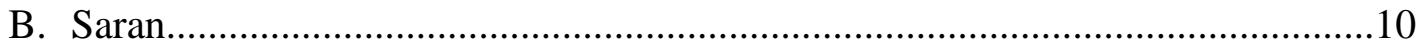

DAFTAR PUSTAKA 


\section{BAB I PENDAHULUAN}

\section{A. Latar Belakang}

Al-Qur'an selain sebagai kitab suci bagi umat Islam mengatur hubungan individu dengan Tuhannya, juga merupakan kitab yang memberikan pedoman hidup secara individu dengan individu lain, maupun secara bersama masyarakat bagi seluruh umat manusia. Makalah ini sesungguhnya berupaya untuk menggali lebih jauh ajaran-ajaran Alqur'an khususnya yang terkait dengan stratifikasi sosial yang ada di dalam masyarakat. Pelapisan-pelapisan yang terjadi di masyarakat adalah merupakan sebuah keniscayaan keberadannya. Setiap masyarakat memiliki tatanan, norma, nilai, yang dianutnya. Hal ini termasuk juga pada masyarakat dalam pandangan al-Qur'an. Setiap kelompok masyarakat memiliki sesuatu hal yang mengandung nilai-nilai yang dianut dan diagungkannya sesuai dengan falsafah hidupnya masing-masing, termasuk falsafah hidup yang mendasari terwujudnya stratifikasi sosial bagi masyarakat muslim yang harus digali dari dalam al-Qur'an sebagai ajaran wahyu Tuhan untuk kemaslahatan kehidupan umat manusia di muka bumi ini. Masyarakat adalah kumpulan sekian banyak individu kecil atau besar yang terikat oleh satuan, adat istiadat, ritus atau hukum khas, dan hidup bersama. ${ }^{1}$ Dalam pengertian lain, masyarakat merupakan sekumpulan orang yang terdiri dari berbagai kalangan dan tinggal di dalam satu wilayah, kalangan ini bisa terdiri dari kalangan orang mampu hingga orang yang tidak mampu. Masyarakat yang sesungguhnya adalah sekumpulan orang yang telah memiliki hukum adat, norma-norma dan berbagai peraturan yang siap untuk ditaati.Masyarakat juga sering dikenal dengan istilah society yang berarti sekumpulan orang yang membentuk sistem, yang terjadi komunikasi di dalam kelompok tersebut. Menurut Wikipedia, kata Masyarakat sendiri diambil dari bahasa Arab, Musyarak,. Masyarakat juga bisa diartikan sekelompok orang yang saling berhubungan dan kemudian membentuk kelompok yang lebih besar. Biasanya masyarakat sering diartikan sekelompok orang yang hidup dalam satu wilayah dan hidup teratur oleh adat di dalamnya. ${ }^{2}$ Dalam suatu perkembangan daerah, masyarakat bisa dibagi menjadi dua bagian yaitu masyarakat maju dan masyarakat sederhana. Masyarakat maju adalah masyarakat yang memiliki pola pikir untuk kehidupan yang akan dicapainya dengan kebersamaan meskipun berbeda golongan. sedangkan masyarakat sederhana adalah sekumpulan masyarakat yang mempunyai pola pikir yang primitif, yang hanya membedakan antara laki-laki dan perempuan saja. Ahli Sosiologi berpendapat, bahwa dalam semua masyarakat memiliki ketidak samaan di berbagai bidang. Misalnya di dalam bidang ekonomi, sebagian masyarakat memiliki kekayaan yang berlimpah dan kesejahteraan hidup yang terjamin; sedangkan sebagian lainnya dalam keadaan miskin dan tidak sejahtera. Pada bidang politik, sebagian orang memiliki kekuasaan dan sebagian lainnya dikuasai. Inilah realitas sosial dalam masyarakat. Perbedaan anggota masyarakat inilah yang kemudian dinamakan sebagai stratifikasi sosial. ${ }^{3} \mathrm{Al}-\mathrm{Qur}$ 'an selain sebagai kitab suci bagi umat Islam, juga merupakan kitab yang memberikan pedoman untuk hidup secara individu dengan individu lain,

\footnotetext{
1 M. Quraish Shihab, Wawasan al-Qur'an, (Bandung: Mizan, 2007), h. 319

2 Ibid.

${ }^{3}$ Abdullah Idi, Sosiologi Pendidikan: Individu, Masyarakat dan Pendidikan, (Jakarta: Rajawali Press, 2011) , h. 177
} 
maupun secara bersama bermasyarakat bagi umat manusia. Kitab ini sekaligus juga memberikan petunjuk dan ajaran dalam membangun hubungan antar individu, masyarakat dengan Tuhannya. Dalam kenyataannya di lapangan, sudah menjadi sebuah keniscayaan bahwa masyarakat itu senantiasa memiliki tingkatan-tingkatan sesuai dengan karakternya masing-masing. Makalah ini sesungguhnya berupaya untuk menggali lebih jauh ajaran-ajaran al-Qur'an khususnya yang terkait dengan tingkatan-tingkatan dan atau lapisan-lapisan yang terjadi di masyarakat menurut pandangan Islam (al-Qur'an).

\section{BAB II PEMBAHASAN}

\section{A. Stratifikasi Mayarakat Menurut al-Qur’an}

Walaupun al-Qur'an bukan kitab ilmiyah dalam pengertian umum namun kitab suci ini banyak sekali berbicara tentang masyarakat. Ini disebabkan karena fungsi utama kitab suci alQur'an adalah mendorong lahirnya perubahan-perubahan positif dalam masyarakat, atau dalam bahasa al-Qur'an: litukhrija an-nas mina al-dzulumati ila al-nur, mengeluarkan manusia dari gelap gulita menuju cahaya yang terang benerang. ${ }^{4}$ Ada beberapa kata yang digunakan al-Qur'an untuk menunjuk kepada masyarakat atau kumpulan manusia antara lain Qoum, Ummah, Syu'ub dan Qabail $^{5}$. Disamping itu, al-Qur'an juga memperkenalkan masyarakat dengan sifat-sifat tertentu seperti al-mala, al-mustakbirun, al-mustadh afun, dan lainlain. ${ }^{6}$ Setiap masyarakat mempunyai ciri khas dan pandangan hidupnya. Mereka melangkah berdasarkan kesadaran tentang hal tersebut, inilah yang melahirkan watak dan kepribadiannya yang khas. Dalam hal ini al-Qur'an menjelaskan Demikianlah kami menjadikan indah di mata setiap masyarakat perbuatan mereka. ${ }^{7}$ Suasana kemasyarakatan dengan sistem nilai yang dianutnya mempengaruhi sikap dan cara pandang masyarakat itu, demikian juga ukuran-ukuran hal/sesuatu yang dianggap penting dan memiliki nilai lebih akan dianggap sebagai sesuatu yang berharga, dan kemudian melahirkan stratifikasi di dalam masyarakat tersebut. Menurut hemat penulis, selain al-Qur'an sebagai kitab suci, juga berfungsi sebagai petunjuk untuk menata kehidupan umat manusia (Islam), sekaligus merupakan ajaran wahyu dari Tuhan yang memiliki pandangan sendiri tentang masyarakat, dan tentang nilainilai sosial sebagai sebuah sistem aturan (nilai) yang dianutnya. Sistem nilai itulah pada gilirannya menjadikan sesuatu hal/barang menjadi dihargai oleh masyarakt (islam) dan kemudian melahirkan stratifikasi sosial dalam kehidupannya. Nilai-nilai sosial dari ajaran wahyu itu tentunya harus digali terus menerus dari beberapa ayat yang terkandung di dalamnya untuk dijadikan pijakan dalam kehidupan bermasyarakat dewasa ini. Adapun nilai-nilai itu diantara adalah;

\footnotetext{
4 M. Quraish Shihab, Wawasan al-Qur'an, (Bandung: Mizan, 2007), h. 319

5 Ali Nurdin, Qur'anic Sociaty, (Bandung: Erlangga, 2011), h, 20-25

6 M. Quraish Shihab, Wawasan al-Qur'an, 319

7 QS. Al-An'am [6]: 108
} 


\section{B. Iman dan Ilmu}

Hai orang-orang yang beriman, apabila dikatakan kepadamu: "Berlapang-lapanglah dalam majelis", maka lapangkanlah, niscaya Allah akan memberi kelapangan untukmu. Dan apabila dikatakan: Berdirilah kamu, maka berdirilah, niscaya Allah akan meninggikan orangorang yang beriman di antaramu dan orang-orang yang diberi ilmu pengetahuan beberapa derajat. Dan Allah Maha Mengetahui apa yang kamu kerjakan. ${ }^{8}$ Ayat tersebut diatas memberikan penjelasan bahwa; memberi kelapangan kepada sesama manusia (muslim) dalam pergaulan dan usaha mencari ilmu adalah merupakan kebaikan. Berusaha untuk membantu saudara sesama manusia untuk meraih sebuah prestasi dalam kebaikan adalah dianjurkan oleh Rasulullah SAW. Sebagaimana dikutip dalam sebuah haditsnya yang menyatakan: "Allah senantiasa menolong hamba-Nya selama hamba-hamba itu menolong sudara-saudara lainnya." ${ }^{\text {A }}$ Ayat ini juga menjelaskan bahwa, Allah akan mengangkat derajat orang-orang yang beriman, taat dan patuh kepada-Nya, melaksanakan perintah-Nya, menjauhi larangan-Nya, berusaha menciptakan suasana damai, aman dan tenteram, dalam masyarakat, demikian pula orang-orang yang berilmu dan menggunkan ilmunya untuk menegakkan kalimat Allah. Dari ayat ini dipahami bahwa orang-orang yang mempunyai derajat yang paling tinggi di sisi Allah ialah orang-orang yang beriman dan berilmu. Ilmunya itu diamalkan sesuai dengan perintah Allah dan rasul-Nya. ${ }^{10}$ Dalam realitas di masyarakat pada umumnya, orang-orang yang berilmu senantiasa dihormati dan menempati posisi tinggi dibanding orang - orang yang tidak berilmu. Hal ini mendapat legitimasi dari al-Qur'an, bahwa orang-orang yang beriman dan berilmu diangkat derajatnya oleh Allah baik di dunia maupun di akherat. Juga pada kenyataannya di masyarakat dapat dilihat, bagi orang yang memiliki iman dan ilmu akan lebih sejahtera hidupnya di dunia ini bila dibandingkan dengan orang-orang/masyarakat lain yang tidak memiliki iman dan ilmu.

\section{Intelektual/Ulul Albab}

Sesungguhnya dalam penciptaan langit dan bumi, dan silih bergantinya malam dan siang terdapat tanda-tanda bagi orang-orang yang berakal. (yaitu) orang-orang yang mengingat Allah sambil berdiri atau duduk atau dalam keadaan berbaring dan mereka memikirkan tentang penciptaan langit dan bumi seraya berkata Ya Tuhan kami, tiadalah Engkau menciptakan ini dengan sia-sia. Maha Suci Engkau, maka peliharalah kami dari siksa neraka. ${ }^{11}$ Al-Qur'an memuji sekelompok manusia yang dinamainya dengan "Ulil al-bab. Sebagaimana disebutkan pada ayat diatas, bahwa ciri-ciri mereka antara lain yang pertama; mereka suka bertafakkur, dan yang kedua;

\footnotetext{
8 QS. Al-Mujadalah [58):11

9 HR. Muslim dari Abu Hurairah, sebagaimana dikutib dalam Tafsir al-Qur'an dan Terjemahnya. Kementrian Agama. RI, Jilid,10, h. 24

10 Ibid.

11 QS. Ali Imron [3]: 190-191
} 
mereka suka untuk berzikir. ${ }^{12}$ Dikisahkan dalam kitab tafsir al-Qur' an ${ }^{13}$ berkaitan dengan ayat ini, adalah sebuah peristiwa dimana Rasulullah SAW menangis sampai matanya membasahi kainnya, karena merenungkan ayat al-Qur'an yang dibacanya. Setelah shalat beliau duduk memuji Allah dan kembali menangis tersedusedu. Kemudian beliau mengangkat kedua belah tangannya untuk berdoa dan menangis lagi, dan air matanya membasahi tanah. Setelah Bilal datang untuk adzan Subuh dan melihat Nabi SAW menangis ia bertanya Wahai Rasulullah! mengapakah engkau menangis, padahal Allah telah mengampuni dosa-dosa Rasulullah baik terdahulu maupun yang akan datang? Nabi Menjawab, Apakah saya ini bukan seorang hamba yang pantas bersyukur kepada Allah? dan bagaimana saya tidak menangis? Pada malam ini Allah telah menurunkan ayat kepadaku. Selanjutnya beliau berkata, alangkah ruginya dan celakalah orang-orang yang membaca ini dan tidak memikirkan dan merenungkan kandungan artinya". Memikirkan pergantian siang dan malam, mengikuti terbit dan tenggelamnya matahari, siang lebih lama daripada malam dan sebaliknya. Semua itu menunjukkan atas kebesaran dan kekuasaan penciptanya bagi orang-orang yang berakal. Hal inilah sesungguhnya merupakan tantangan sendiri bagi kaum intelektual yang beriman. Salah satu ciri khas bagi orang yang berakal yang merupakan sifat khusus manusia dan kelengkapan ini dinilai sebagai makhluk yang memiliki keunggulan dibanding makhluk lain, yaitu apabila ia memperhatikan sesuatu, selalu memperoleh manfaat dan faedah, ia selalu menggambarkan kebesaran Allah, mengingat dan mengenang kebijaksanaan, keutamaan dan nikmat yang Allah berikan. ${ }^{14}$ Demikian juga dalam QS. Az-Zumar [39], diperintahkan kepada umat manusia muslim untuk menghormati orang yang memiliki keilmuan ulul albab. Katakanlah Adakah sama orang-orang yang mengetahui berilmu dan yang tidak mengetahui berilmu. Sesungguhnya orang yang berakallah yang dapat menerima pelajaran. ${ }^{15}$ Hal ini selaras dengan ajaran Rasulullah Muhammad SAW, sebagaimana yang diriwayatkan oleh Imam Muslim: "bahwa yang berhak mengimami menjadi pemimpin bagi suatu kaum adalah yang paling ahli membaca al-Qur'an. ${ }^{16}$ Jika bacaan mereka sama, maka yang berhak menjadi imam ialah yang paling mengerti tentang sunnah. Kalau dalam hal sunnah sama, maka yang berhak menjadi imam adalah diantara mereka yang lebih dulu hijrahnya. Jika hijrahnya sama, maka yang berhak lebih dulu untuk menjadi imam adalah orang yang lebih senior usianya. Dan janganlah sesorang mengimami orang lain di tempat kekuasannya, dan janganlah ia duduk di rumahnya di atas tempat khususnya kecuai seizinnya". ${ }^{17}$ Dalam prakteknya di masyarakat orang-orang yang tergolong ulu albab adalah mereka-meraka yang memilki ilmu pengetahuan baik pengetahuan ilmu alam atau ilmu sosial ataupun ilmu-ilmu lainnya termasuk ilmu agama yang menghantarkan mereka untuk mengenal Allah lebih dekat lagi dan sekaligus menambah keimanan dan ketaqwaan kepadaNya. Bila

12 M. Quraish Shihab, Wawasan al-Qur'an, 442-443

13 Kementrian Agama RI, Al-Qur'an Dan Tafsirnya, Edisi Revisi, Jilid 2, (Jakarta: Widya Cahaya, 2011), h. 97-98

14 Ibid

15 Ahmad Muhammad Yusuf, Ensiklopedi Tematis Ayat al-Qur'an dan Hadits, Jilid 4, (Jakarta: Widya Cahaya; 2009), h. $10-11$

${ }^{16}$ Ini berarti bahwa kaum terdidik, cerdik-cendekia, ulama'/intelektual mendapatkan posisi utama di masyarakat karena keberadaan ilmunya.

17 Ibid. 11 
dikaitkan dengan ilmu sosiologi, menurut hemat penulis, potensi inilah yang sesungguhnya merupakan sesuatu yang bisa membedaan seorang manusia intelektual yang beriman dengan manusia lain pada umumnya, yang pada gilirannya mewujudkan perbedan status dan perbedaan stratifikasi di dalam masyarakat.

\section{Amal Perbuatan}

Dan katakanlah Bekerjalah kamu, maka Allah dan Rasul-Nya serta orang-orang mukmin akan melihat pekerjaanmu itu, dan kamu akan dikembalikan kepada Allah Yang Mengetahui akan yang gaib dan yang nyata, lalu diberitakan-Nya kepada kamu apa yang telah kamu kerjakan. ${ }^{18}$

Dalam ayat ini Allah memerintahkan kepada Rasulnya, agar beliau mengatakan kepada kaum muslimin yang mau bertaubat dan membersihkan diri dari dosa-dosa dengan cara bersedekah dan mengeluarkan zakat dan melakukan amal shaleh sebanyak mungkin. ${ }^{19}$ Disamping itu, Allah juga memerintahkan kepada rasul-Nya agar menyampaikan kepada umatnya, bahwa apabila mereka telah melakukan amal-amal shaleh tersebut maka Allah dan rasul-Nya serta orang-orang mukmin lainnya akan melihat dan menilai amal-amal tersebut. ${ }^{20}$ Pada akhirnya mereka akan dikembalikan ke alam akhirat, dan akan diberikan ganjaran/pahala yang baik di surga-Nya kelak. Ini berarti bahwa, manusia akan dinilai dari seberapa jauh amal perbuatan baik atau buruk yang dilakukanya di masyaraakat, hal ini menurut hemat penulis, selaras dengan teori peran yang melihat manusia dinilai berdasarkan perannya masing-masing di lingkungannya. Dalam kajian sosiologi manusia akan dinilai oleh kelompok masyarakat lainnya dari seberapa jauh mereka memiliki peran yang telah dilakukan di dalam lingkungannya. Setiap peran sosial adalah serangkaian hak, kewajiban, harapan, norma, dan perilaku seseorang yang harus dihadapi dan dipenuhi. Model ini didasarkan pada pengamatan bahwa orang-orang bertindak dengan cara yang dapat diprediksikan, dan bahwa kelakuan seseorang bergantung pada konteksnya, berdasarkan

posisi sosial dan faktor-faktor lainnya. ${ }^{21}$ Sosiolog Robert Park dari Universitas Chicago memandang bahwa masyarakat mengorganisasikan, mengintegrasikan, dan mengarahkan kekuatan-kekuatan individu-individu ke dalam berbagai macam peran (roles). Melalui peran inilah kita menjadi tahu siapa diri kita. Kita adalah seorang anak, orang tua, guru, mahasiswa, laki-laki,

18 QS. Al-Taubah [9]: 105

${ }^{19}$ Abdullah Bin Muhammad Alu Syaikh, Lubab al-Tafsir min Ibn Kathir., Terjemah (Jakarta: Pustaka Imam Syafi'i, 2012), h.

${ }^{20}$ Kementrian Agama RI, Al-Qur'an dan Tafsirnya, Jilid 4. (Jakarta: Widya Cahaya: 2011), h. 201

${ }^{21}$ http://id.wikipedia.org/wiki/Teori_peran 
perempuan, Islam, Kristen. Konsep kita tentang diri kita tergantung pada peran yang kita lakukan dalam masyarakat. ${ }^{22}$

\section{E. Kekuasaan}

Katakanlah Wahai Tuhan Yang mempunyai kerajaan, Engkau berikan kerajaan kepada orang yang Engkau kehendaki dan Engkau cabut kerajaan dari orang yang Engkau kehendaki. Engkau muliakan orang yang Engkau kehendaki dan Engkau hinakan orang yang Engkau kehendaki. Di tangan Engkaulah segala kebajikan. Sesungguhnya Engkau Maha Kuasa atas segala sesuatu."23

Menurut ayat diatas, timbulnya kekuasaan pada diri manusia adalah semata-mata pinjaman dari Allah SWT, ${ }^{24}$ Dan Engkau muliakan barang siapa yang Engkau kehendaki dan Engkau hinakan barang siapa yang kehendaki Seluruh kekuasaan di langit dan di bumi semuanya adalah miliknya Allah SWT. ${ }^{25}$ Ayat ini sesunggunya memiliki arti bahwa kekuasaan yang diberikan kepada manusia di dunia ini adalah bersifat sementara dan merupakan pinjaman. Dalam konteks sosiologi, Menurut Max Weber, kekuasaan adalah kesempatan change probability yang ada pada seseorang/sejumlah orang untuk melaksanakan kemauannya sendiri dalam suatu tindak sosial, meskipun mendapat tantangan dari orang lain yang terlibat dalam tindakan itu. Kesempatan merupakan suatu konsep yang sangat inti dalam sosiologi. ${ }^{26}$ Lebih lanjut menurut Max Weber kekuasaan/otoritas merupakan legitimasi sosial. Weber menyebutkan tiga jenis otoritas, yaitu otoritas tradisional, kharismatik, dan legal rasional/birokratis. ${ }^{27}$ Hal demikian menurut hemat penulis berbeda dengan pandangan alQur'an islam yang menyatakan bahwa kekuasaan merupakan amanah dan pinjaman dari Allah SWT untuk dapat ditunaikan/dilaksanakan dengan sebaikbaiknya. Kekuasaan dalam islam (al-Qur'an) dipandang tidak hanya sekedar prestise dalam hidup akan tetapi merupakan sebuah prestasi dan bagian ibadah serta tugas yang mulia untuk dijalankan

22 http://rinawahyu42.wordpress.com/2011/06/07/teori-peran-rhole-theory/

23 QS. Ali Imron, [3]: 26

${ }^{24}$ Hamka, Tafsir al-Azhar, Jilid 3 ( Jakarta: Pustaka Panji Mas, 1983), h. 142

25 Ibid, 141

26 http://www.bangmu2.com/2012/12/pengertian-kekuasaan-dalam-sosiologi.html

27 http://id.shvoong.com/social-sciences/sociology/2228260-kekuasaan-dalam-kajiansosiologi /\#ixzz 2heb010lo 
sesuai dengan norma-norma yang berlaku di masyarakat untuk mewujudkan tatanan kehidupan yang rahmatan li al-alamin.

\section{BAB III PENUTUP}

\section{A. KESIMPULAN}

Pelapisan-pelapisan yang terjadi di masyarakat adalah merupakan sebuah keniscayaan keberadannya. Hal ini termasuk masyarakat ideal dalam pandangan al-Qur'an. Setiap kelompok masyarakat memiliki sesuatu hal yang mengandung nilai-nilai yang dianut dan diagungkannya sesuai dengan falsafah hidupnya masing-masing. Dalam masyarakat Islam pelapisan-pelapisan itu dianut berdasarkan nilai-nilai yang tercantum dalam kitab sucinya yaitu al-Qur'an dan ajaran rasul Muhammad SAW. Bila diamati dari pembahasan terdahulu dapat ditegaskan bahwa; alQur'an merupakan wahyu Tuhan yang mengatur hubungan manusia dengan Tuhan, diri sendiri, dan lingkungan fisik, sosial, budaya. Kitab ini diturunkan merupakan petunjuk etika, kebijaksanaan dan dapat menjadi setidaknya Grand Theory46 dalam ilmu sosial khusunya terkait dalam bidang kemasyarakatan. Potret karakteristik masyarakat dalam al-Qur'an memiliki norma dan nilainilai yang sesuai dengan ajaran wahyu bertujuan untuk membimbing masyarakat itu sendiri. Pada setiap masyarakat pasti ditandai dengan adanya satu hal ketidaksamaan struktur yang tampak pada sejumlah pengaturan institusi sosialnya. Stratifikasi sosial atau pelapisan sosial pada dasarnya berbicara tentang penguasaan sumber-sumber sosial. Sumber sosial adalah segala sesuatu yang oleh masyarakat dipandang sebagai suatu yang berharga. Stratifikasi sosial adalah pembedaan penduduk atau masyarkat ke dalam kelas-kelas secara hierarkis bertingkat. Pelapisan sosial diatas, tentunya tidak berlaku umum, sebab setiap kota ataupun desa masing-masing memiliki karakteristik yang berbeda. Pernyataan ini paling tidak menggambarkan bagaimana kelas sosial itu sebenarnya terjadi. Sebagaimana penjelasan di atas, al-Qur'an sebagai kitab wahyu mengakui dan meletigimasi keberadaan stratifikasi sosial di dalam sebuah masyarakat, hal ini tidak berarti, karakteristik stratifikasi sosial dalam al-Qur'an sama persis dengan teori sosiologi modern, akan tetapi tentunya karakteristik stratifikasi masyarakat dalam pandangan al-Qur'an memiliki corak sendiri. Hal ini tentunya akan disesuaikan dengan arah misi /falsafah kehidupan umat manusia menurut ajaran Tuhan (Allah). Semangat dari nilai perwujudan dan keberadaan pelapisanpelapisan sosial dalam masyarakat dengan berbagai macam corak dan motifnya akan senantiasa berkembang dan berubah sesuai dengan tuntutan dan perubahan paradigma yang berlaku di hadapaan masyarakat itu. Hal ini menurut hemat penulis senantiasa ditemuai di dalam ajaran alQur'an yang berfungsi sebagai pedoman hidup yang selalu aktual. 


\section{B. SARAN}

Penulis tentunya masih menyadari jika makalah ini masih terdapat banyak kesalahan dan jauh dari kesempurnaan. Penulis akan memperbaiki makalah tersebut dengan beRpedoman pada banyak sumber serta kritik yang membangun dari para pembaca.

\section{DAFTAR PUSTAKA}

Chirzin, Muchammad. Buku Pintar Asbabun Nuzul, Mengerti Peristiwa dan Pesan Moral di Balik Ayat-Ayat Suci Al-Qur'an, Jakarta: Zaman, 2011.

Ely Chinoy, Society, An Introduction To Sociology, New York: Random House, 1961.

http://www.rumahbaca.com/1891/pengertian-masyarakat/

Idi, Abdullah. Sosiologi Pendidikan: Individu, Masyarakat dan Pendidikan, Jakarta: Rajawali Press, 2011.

Jurgi, Syarifuddin. Sosiologi Islam \& Masyarakat Modern; Teori Fakta dan Akai Sosial Jakarta: Prenada Media Group, 2010.

Kahmad, Dadang. Sosiologi Agama, Bandung: Remaja Rosda Karya, 2009.

Kelsell, R,K dan H.M. Kellsel, Social Process: Aspects Of Modern Siciology, New York: Long Man Group, 1974

Kementrian Agama RI, Al-Qur'an Dan Tafsirnya, Edisi Revisi, Jakarta: Widya Cahaya, 2011.

Linton, Ralph. The Studi of Man, An Introduction. New York: Aplleton Century. Crofs, 1956.

Muhammad Alu Syaikh, Abdullah Bin. Lubab al-Tafsir Min Ibn Kathir, Terjemah Jakarta: Pustaka Imam As-Syafi'i, 2012.

Muhammad Yusuf, Ahmad. Ensiklopedi Tematis Ayat al-Qur'an dan Hadits, Jakarta: Widya Cahaya; 2009.

Nurdin, Ali. Qur'anic Sociaty, Bandung: Erlangga, 2010

Roucek dan Warren, Sociology an Introduction, New Jesey: Littelfield, Adams \&co, 1962. 
Shihab . M. Quraish, Wawasan al-Qur'an, Bandung: Mizan, 2007.

Soekanto, Soerjono. Sosiologi Suatu Pengantar, Jakarta: Rajawali Press, 1986.

Soemardjan, Selo dan Soelaeman Soemardi, Setangkai Bunga Sosiologi, Jakarta: Yayasan Penerbit Fakultas Ekonomi Universitas Indonesia, 1964. 